\title{
Structure of financing investments in the energy sector
}

\author{
Barbara Kowal ${ }^{1, *}$, Robert Ranosz ${ }^{2}$, Wiktoria Sobczyk ${ }^{3}$ \\ ${ }^{1}$ Faculty of Mining \& Geoengineering, AGH University of Science \& Technology, Al. Mickiewicza \\ 30, 30-059 Krakow, Poland \\ ${ }^{2}$ Faculty of Mining \& Geoengineering, AGH University of Science \& Technology, Al. Mickiewicza \\ 30, 30-059 Krakow, Poland \\ ${ }^{3}$ Faculty of Mining \& Geoengineering, AGH University of Science \& Technology, Al. Mickiewicza \\ 30, 30-059 Krakow, Poland
}

\begin{abstract}
The purpose of this article is to discuss the issues of financing investments in the fuel and energy sector. The manner of financing business activities of every company depends on the decisions made by the management board, which need to take into consideration the effective striving for optimal level of the capital cost. The capital raised by the companies from the aforesaid sector may be in the form of equity or outside capital.

This study depicts such sources of capital as bank loans and corporate bonds considered outside capital as well as the issue of shares included in the equity. It is important for the managers making decisions on different types of financing investments in the energy sector to consider the capital cost. The outside capital cost shall be deemed to mean the interest rate on bank loans and corporate bonds, whereas the cost of equity shall be calculated on the basis of the Capital Asset Pricing Model (CAPM). The cost includes both the loss of profit represented by the risk-free rate (which is usually assumed at the level of 10-year old treasury bonds) and the risk to which the capital owner is exposed. The CAPM is usually used for determining the investment risk in a given company.

The article shows how the financing structure of the companies from the fuel and energy sector, listed on the Warsaw Stock Exchange, has evolved over the years. The authors also estimated the cost of equity. The results were compared with the chosen mining companies in Poland. Companies from the energy sector have lower investment risk than companies from the fuel sector. Looking at the profitability of investments it should be emphasized that the financing by outside capital is more advantageous than equity financing.
\end{abstract}

\section{Introduction}

Running business activities in the sector of companies operating on the energy and fuel market entails the necessity of making both financial and investment decisions. As part of

\footnotetext{
* Corresponding author: bkowal@agh.edu.pl
} 
the investment decision-making process, a company needs to decide on the distribution of funds it managed to raise. On the other hand, the financial decisions make it necessary to choose appropriate sources of financing the planned investments. The selection of right sources of financing affects both the value of the implemented investment and the value of the company itself. A real impact on the choice of the source of financing have, among other things, such factors as: availability of capital and its cost. When considering the source of capital in the context of the investment efficiency, the capital structure determining the financial standing of each entity is not insignificant. Companies finance their business activities either from their equity (usually with limited access) or from third party equity, which is cheaper than their equity. An additional benefit derived from the financing of investment activities through outside capital is the fact that the interest paid on the obtained outside capital increases the operating costs of the business run and hence allows the company to pay lower income tax. However, it must be remembered that continuous accumulation of debts in a company is not beneficial and consequently may lead to the increase of costs of the raised capital or bankruptcy. Therefore, the choice of appropriate sources of capital for financing investments in the fuel and energy sector is an important factor, especially that it is characterized by capital intensity and long investment cycle. Their activities are subject to special social responsibility. On one hand, they must run their business activities efficiently and achieve their basic economic goals, but on the other - they need to remember (due to their nature) about the principles of sustainable development and social responsibility $[7,11,8]$. To efficiently implement the strategy and assumed goals, the management staff needs to invest financial resources in the business activity [3].

The authors of this article decided to investigate the capital structure of companies from the above-mentioned sectors and estimate the amount of the cost of equity held thereby. A number of methods, such as DGM, LEFAC and CAPM [9] may be used to estimate the cost of equity. In this article, one of the most popular methods, i.e. CAPM, was used to estimate the cost of equity.

\section{Structure of financing}

Equity is a capital good, which allows entities to run their business activities and to develop, which contributes to the increase of their goodwill and which allows them to achieve and maintain competitive advantage on the market. Equity is the capital brought in by the owners for an indefinite period of time. On the other hand, funds paid by creditors should be used by a company for a definite period of time (reimbursement on a specific date).

Business activities depend, among other things, on the structure of the sources of financing, which currently constitutes one of the most widely discussed issues in the field of finance [5]. The capital structure is reflected in maintaining appropriate proportions between equity and foreign equity. In the subject literature, the capital structure is not defined in an unambiguous manner. Some authors believe that it is the following $[6,12,4,2,10,1]$ :

- level of general indebtedness,

- structure of liabilities, which constitutes the structure of financing business of each entity,

- total share of long-term liabilities in the capital,

- structure of securities issued by a company (debt securities, proprietary shares),

- as ratio: (third party equity/equity) +1 regardless of the due date.

Undoubtedly, it is the long-term capital that plays key role in the creation of the capital structure, which in turn has impact on the weighted average cost of capital of a company.

The authors analysed the financing structure in companies from the energy and fuel industry, listed on the Warsaw Stock Exchange in 2013-2015. Eight companies from the 
energy sector and three from the fuel sector were taken into account. At the beginning of the analysis, it was assumed that all sources of capital held by a given entity had to be included in equity, whereas the entirety of its liabilities constituted third party equity.

When analysing the financing structure, the share of outside capital in the entire financing capital for particular companies in the above-mentioned sectors was determined, which is shown in figure 1.

Table 1. Share of outside capital in financing for companies from the energy and fuel sector.

\begin{tabular}{|l|c|c|c|}
\hline Companies from the energy sector & $\mathbf{2 0 1 3}$ & $\mathbf{2 0 1 4}$ & $\mathbf{2 0 1 5}$ \\
\hline ELEKTR. BEDZIN S.A. & $37.8 \%$ & $30.0 \%$ & $67.7 \%$ \\
\hline ENEA S.A. & $29.8 \%$ & $33.7 \%$ & $50.7 \%$ \\
\hline ENERGA S.A. & $53.0 \%$ & $53.0 \%$ & $52.5 \%$ \\
\hline ZESP. ELEKTR. WR. KOG. S.A. & $38.2 \%$ & $40.1 \%$ & $39.4 \%$ \\
\hline POLENERGIA S.A. & $45.8 \%$ & $51.2 \%$ & $56.3 \%$ \\
\hline PGE S.A. & $28.9 \%$ & $32.4 \%$ & $34.2 \%$ \\
\hline TAURON S.A. & $46.4 \%$ & $48.0 \%$ & $50.1 \%$ \\
\hline ZESP. ELEKTROW. P-A-K S.A. & $41.5 \%$ & $44.4 \%$ & $62.1 \%$ \\
\hline Companies from the fuel sector & $\mathbf{2 0 1 3}$ & $\mathbf{2 0 1 4}$ & $\mathbf{2 0 1 5}$ \\
\hline GRUPA LOTOS S.A. & $54.7 \%$ & $56.4 \%$ & $59.8 \%$ \\
\hline PGNiG S.A. & $41.2 \%$ & $38.3 \%$ & $38.3 \%$ \\
\hline PKN ORLEN S.A. & $49.5 \%$ & $59.8 \%$ & $53.9 \%$ \\
\hline
\end{tabular}

Source: own elaboration on the basis of data [13]

On the basis of percentage shares in the financing structure (table 1), it is evident that in the analysed period, the share of outside capital in the entire financing capital in case of the companies from the energy sector fluctuated between $28.9 \%$ and $67.7 \%$. Two companies had a comparable share of this capital (Energa S.A., Zespół Elektr. Wrocławskich Kogeneracja S.A.), in other two - a slight increase of share of approx. 5 p.p. was noted (PGE S.A., Tauron Polska Energia S.A.), whereas a more significant increase of approx. 10 p.p. was observed in only one company (Polenergia S.A.). On the other hand, the remaining three companies experienced a considerable change in the analysed years of the outside capital share. The share fluctuated respectively: in Elektrociepłownia Będzin S.A. from $37.8 \%$ to $80.7 \%$, in Enea S.A. from $29.8 \%$ to $50.7 \%$ and in Zespół Elektrowni Pątnów-Adamów-Konin S.A. from $41.5 \%$ to $62.1 \%$. The financing structure shows that especially in the first two periods of analysis, the level of equity was higher than the level of debts (third party equity).

In the companies from the fuel sector, the share of outside capital is comparable to the level of the majority of companies from the energy sector. In the analysed period, it is maintained at the similar level. The increased share of the analysed capital was noted in case of two companies (Grupa Lotos S.A. from 54.7\% to 59.8\%, Polski Koncern Naftowy Orlen S.A. from $49.5 \%$ to $53.9 \%$ ), whereas in case of one listed company - Polskie Górnictwo Naftowe i Gazownictwo S.A. - the share decreased from $41.2 \%$ to $38.3 \%$. 


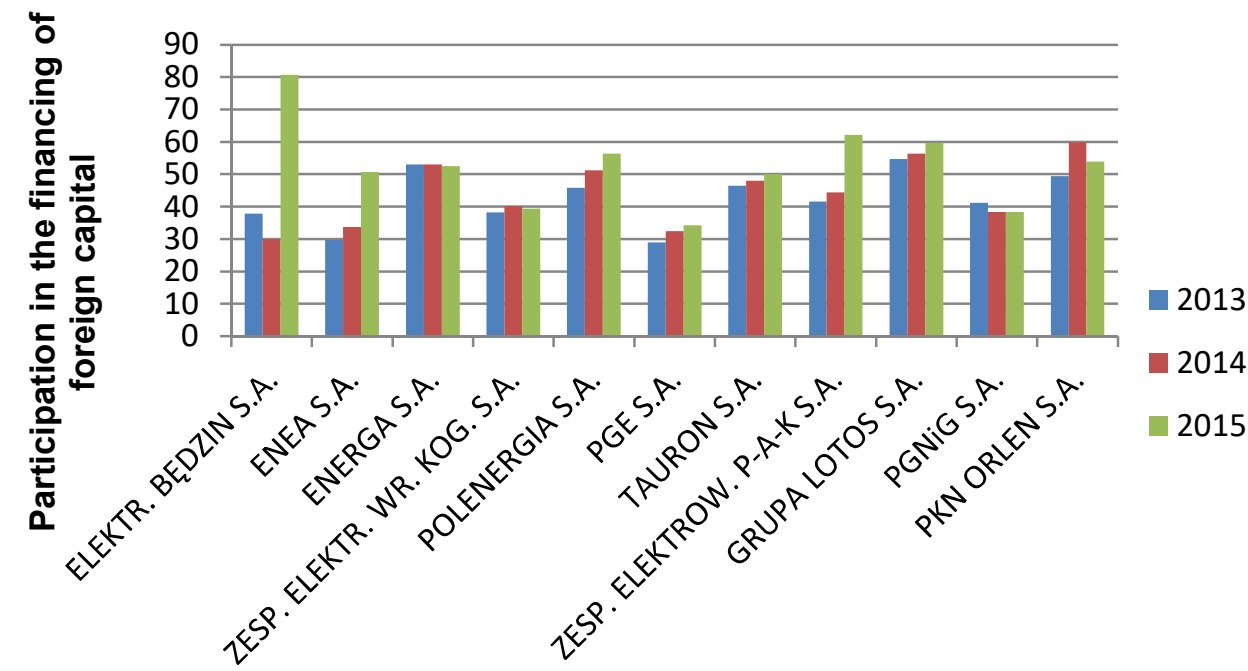

\section{Company}

Fig. 1. Share of outside capital in the entire financing capital for companies from the energy and fuel sector, listed on the Warsaw Stock Exchange in 2013-2015.

Source: own elaboration on the basis of data [13]

The energy sector is less stable than fuel sector. The level of share of outside capital in the entire financing capital in six out of eight of the analysed companies significantly increased by comparison with the initial period (2013), exceeding 50\%. In Elektrociepłownia Będzin S.A. - the level exceeded $67 \%$. The companies from the fuel sector shape their financing structure in a more stable manner, thus, the level of share in the years 2013-2015 was not subject to significant fluctuations.

\section{Cost of equity}

The indebtedness of companies increases the investment risk, which in turn should cause an increase of the cost of equity. When calculating such cost, apart from the risk free interest rate, the risk of investment into a given company is also estimated. The Authors used one of the most popular methods of estimating cost of equity, namely the CAPM. The cost of equity for each company (table 3 ) was calculated according to the following formula (1):

$$
\mathrm{CAPM}=\mathrm{r}_{\mathrm{e}}+\left(\mathrm{r}_{\mathrm{m}}-\mathrm{r}_{\mathrm{e}}\right) * \beta
$$

where:

$r_{m}$ - market rate (determined based on the WIG)

$\mathrm{r}_{\mathrm{e}}$ - risk-free rate

$\beta$ - beta factor

The $\beta$ factor was calculated separately for each listed company from both the energy sector and fuel according (table 2) to the formula (2):

$$
\beta=\frac{\operatorname{cov}\left(r_{\text {tested }} ; r_{m}\right)}{s^{2}\left(r_{m}\right)}
$$


Table 2. Beta factor for companies from the energy and fuel sector.

\begin{tabular}{|l|c|c|c|}
\hline Companies from the energy sector & $\mathbf{2 0 1 3}$ & $\mathbf{2 0 1 4}$ & $\mathbf{2 0 1 5}$ \\
\hline ELEKTR. BĘDZIN S.A. & 0.169 & 0.164 & 0.174 \\
\hline ENEA S.A. & 0.554 & 0.583 & 0.629 \\
\hline ENERGA S.A. & 0.613 & 0.681 & 0.730 \\
\hline ZESP. ELEKTR. WR. KOG. S.A. & 0.448 & 0.447 & 0.434 \\
\hline POLENERGIA S.A. & 0.566 & 0.547 & 0.540 \\
\hline PGE S.A. & 0.955 & 0.944 & 0.978 \\
\hline TAURON S.A. & 0.854 & 0.870 & 0.919 \\
\hline ZESP. ELEKTROW. P-A-K S.A. & 0.714 & 0.735 & 0.771 \\
\hline Companies from the fuel sector & $\mathbf{2 0 1 3}$ & $\mathbf{2 0 1 4}$ & $\mathbf{2 0 1 5}$ \\
\hline GRUPA LOTOS S.A. & 1.095 & 1.075 & 1.067 \\
\hline PGNiG S.A. & 0.735 & 0.760 & 0.774 \\
\hline PKN ORLEN S.A. & 1.141 & 1.147 & 1.136 \\
\hline
\end{tabular}

Source: own elaboration on the basis of data [13]

The following assumptions were made: the risk free interest rate was adopted at the level of the 10 -year old treasury bonds, i.e. $2.5 \%$, whereas the market rate was adopted at the level of $7 \%$. With such assumptions, the cost of equity for the companies from the energy sector and fuel sector was estimated. The results of the calculations are presented in table 3 and figure 2 .

Table 3. Cost of equity calculated by using the CAPM.

\begin{tabular}{|l|l|l|l|}
\hline Companies from the energy sector & $\mathbf{2 0 1 3}$ & $\mathbf{2 0 1 4}$ & $\mathbf{2 0 1 5}$ \\
\hline ELEKTR. BEDDZIN S.A. & $3.26 \%$ & $3.24 \%$ & $3.28 \%$ \\
\hline ENEA S.A. & $4.99 \%$ & $5.12 \%$ & $5.33 \%$ \\
\hline ENERGA S.A. & $5.26 \%$ & $5.57 \%$ & $5.79 \%$ \\
\hline ZESP. ELEKTR. WR. KOG. S.A. & $4.52 \%$ & $4.51 \%$ & $4.45 \%$ \\
\hline POLENERGIA S.A. & $5.04 \%$ & $4.96 \%$ & $4.93 \%$ \\
\hline PGE S.A. & $6.80 \%$ & $6.75 \%$ & $6.90 \%$ \\
\hline TAURON S.A. & $6.34 \%$ & $6.42 \%$ & $6.64 \%$ \\
\hline ZESP. ELEKTROW. P-A-K S.A. & $5.71 \%$ & $5.81 \%$ & $5.97 \%$ \\
\hline Companies from the fuel sector & $\mathbf{2 0 1 3}$ & $\mathbf{2 0 1 4}$ & $\mathbf{2 0 1 5}$ \\
\hline GRUPA LOTOS S.A. & $7.43 \%$ & $7.34 \%$ & $7.30 \%$ \\
\hline PGNiG S.A. & $5.81 \%$ & $5.92 \%$ & $5.98 \%$ \\
\hline PKN ORLEN S.A. & $7.64 \%$ & $7.66 \%$ & $7.61 \%$ \\
\hline
\end{tabular}

Source: own elaboration on the basis of data [13]

Average cost of equity in case of companies from the energy sector oscillates in the range of 4 p.p. (from $3.26 \%$ to $6.90 \%$ ). In six companies, the cost of capital increased in the analysed period from $0.02 \%$ to $0.53 \%$ (Elektrociepłownia Będzin S.A. by 0,02 p.p., Enea S.A., Energa S.A., PGE Polska Grupa Energetyczna S.A., Tauron Polska Energia S.A., Zespół Elektrowni Pątnów-Adamów-Konin S.A.), in the other two - the level of this cost decreased (Zespół Elektr. Wrocławskich Kogeneracja S.A. by 0.07 p.p., Polenergia S.A. by 0.11 p.p.). 
On the other hand, in the fuel sector, the average cost of equity oscillated in the range of 2 p.p. (from $5.81 \%$ to $7.66 \%$ ). In only one company, the cost of capital increased from $5.81 \%$ to $5.98 \%$ (PGNiG S.A.), in others - the cost slightly decreased in comparison with the analysed period (Grupa Lotos S.A. by 0.13 p.p., Polski Koncern Naftowy Orlen S.A. by 0.03 p.p.).

Table 4. Cost of equity for the selected mining companies.

\begin{tabular}{|l|c|}
\hline \multicolumn{1}{|c|}{ Company } & Cost of equity \\
\hline KGHM S.A. & $7.53 \%$ \\
\hline JSW S.A. & $8.45 \%$ \\
\hline KHW S.A. & $13.05 \%$ \\
\hline Bogdanka S.A. & $3.99 \%$ \\
\hline KW S.A. & $11.07 \%$ \\
\hline
\end{tabular}

Source: own elaboration on the basis of data [13]

To compare the amount of the cost of equity, its amount in 2015 was calculated for the selected mining companies, as shown in table 4. In case of similar financing structure of such companies (outside capital did not exceed 50\%), compared to the financing structure of the companies from the energy and fuel sector, the cost was at a slightly higher level. Only in case of two companies (KGHM S.A. and Bogdanka S.A.), the cost was comparable to the cost of capital of the analysed energy and fuel companies.

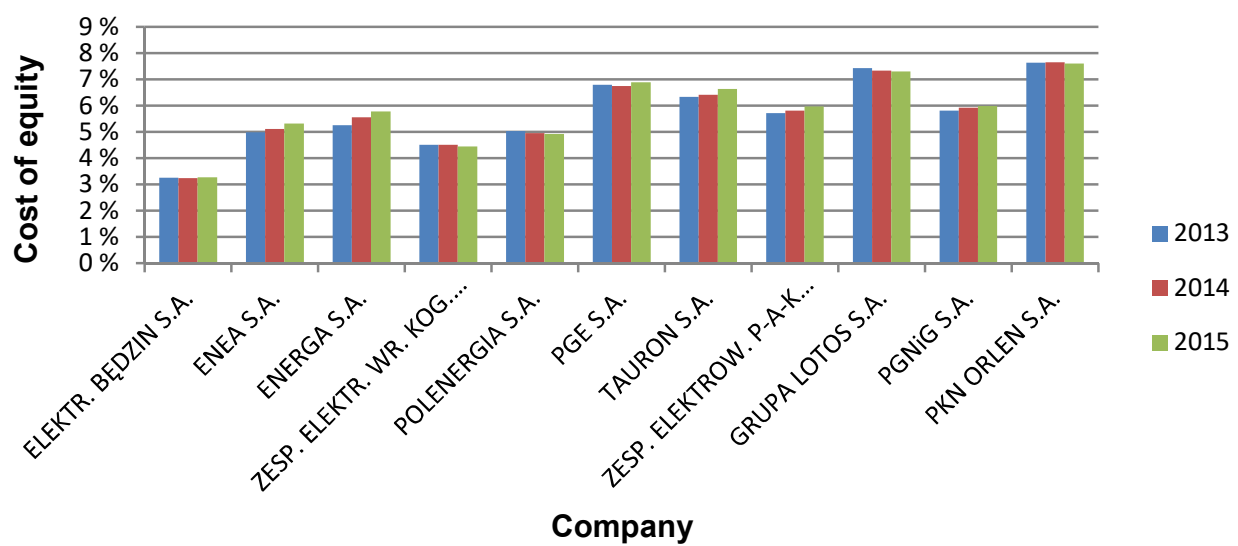

Fig. 2. Cost of equity for the companies from the energy and fuel sector in 2013-2015

Source: own elaboration on the basis of data [13]

According to the performed analysis, the cost of equity of the companies from the energy sector is lower than that of the companies from the fuel sector. Therefore, it may be concluded that according to investors, investment into the fuel sector is more risky than into the energy sector (higher cost of equity). When analysing the results obtained in the previous chapter (financing structure), it must be confirmed that there is a correlation between indebtedness 
of the companies from the above-mentioned sectors and the cost of equity. It should be also assumed that the cost of third party equity shall also increase.

\section{Summary}

Companies from the energy sector have lower investment risk than companies from the fuel sector. This difference may be due to the fact that enterprises of the fuel sector in the course of their business activities are exposed to more risks factors than companies from the energy sector. These main factors distinguishing these two sectors in terms of risk is that the susceptibility of financial performance (and therefore dividends) changes in foreign exchange rates and raw material (crude oil or natural gas).

In the case of companies in the energy sector there are no such threats as to changes in the price of energy, because mainly they are regulated. The article also shows the cost of equity for companies in the mining sector. The risk of investing in these companies is much higher than those analyzed in the article. The aim of showing that the risk in the mining sector is so high are the last "plans" for a merger of mining companies with companies from the energy sector. If such connections that occurred on a larger scale then it is expected that the cost of equity of energy companies would be falling growth.

Of course financing investments by foreign capital means a smaller tax base for each company. That causes the companies would pay less income tax in practice. Looking at the profitability of investments it should be emphasized that the financing by outside capital is more advantageous than equity financing.

The publication of the article was financed from statutory activities AGH agreement no 11.11.100.693

\section{References}

1. R. A. Brealey, S. C. Myers, Principles of Corporate Finance, McGraw Hill, New York (1991)

2. J. Downes, J. E. Goodman, Dictionary of Finance and Investment Terms. Barron's Educational Series, Inc., Hauppauge (1991)

3. W. Gabrusewicz, Podstawy analizy finansowej, PWE, Warszawa (2007)

4. E. A. Helfert, Techniques of Financial Analysis. A Practical Guide to Managing and Measuring Business Performance, Irwin, Burr Ridge (1994)

5. B. Jakubczyk, J. Lewandowska, Teorie struktury kapitału $w$ literaturze swiatowej, Finanse i Prawo Finansowe, JOFFL, Kwartalnik, I(4): p. 65-81, I, No. 4 (December 2014)

6. M. Jasiniak, R. Pastusiak, W. Starzyński, Struktura kapitału a efektywność funkcjonowania przedsiębiorstw sektora energetyki w krajach Europy, W: Finansowe $i$ organizacyjne aspekty kooperacji nauki i lokalnej przedsiębiorczości, ed. M. Wypych, P. Trippner, Przedsiębiorczość i Zarządzanie, Wydawnictwo SAN, Tom XV, Zeszyt 10, Część I, p. 53-63, Łódź-Garwolin (2014)

7. B. Kowal, D. Kowal, The sustainable development management system of hard coal mining enterprises, PJoES, ISSN 1230-1485, 20, No. 4A, p. 145-150 (2011)

8. B. Kowal, A. Kustra, Reporting of sustainable development strategy in energy industry, E3S Web of Conferences 10, 00129 (2016) 
9. R. Ranosz, Estimation of the cost of equity for mining companies using the P-LEFAC method, ARCH MIN SCI, 59, No 1, p. 257-269 (2014)

10. S. A. Ross, R.W. Westerfield, J. Jaffe, Corporate Finance, Irwin, Chicago (1996)

11. W. Sobczyk, Sustainable development of rural areas, PS, 9, No. 1, p. 119-126 (2014)

12. M. B. Tudose, Capital Structure and Firm Performance, ETCognition, 15, No. 2 (2012)

13. www.bankier.pl 